UDC 656.6

DOI https://doi.org/10.32838/2663-5941/2020.1-2/25

Malaksiano M.O.

Odessa National Maritime University

\title{
Melnyk O.M.
}

Odessa National Maritime University

\section{VESSEL SELECTION PROSPECTS AND SUITABILITY ASSESSMENT FOR OVERSIZED CARGO TRANSPORTATION}

The countries of Southeast Asia are the largest importers of bulk cargoes in the world, as well as exporters of large volumes of oversized project cargo including unique equipment consisting of heavy-lifts and out of gauge units, which are carried on board of specialized ships, specially designed build for this type of transportation. A large number of dry cargo vessels, including bulk carriers and container ships that formed free tonnage in this geographical area, remain mainly unloaded in the reverse direction and therefore have to return in ballast condition. The way of assessment of the possibility of using such non-specialized vessels for the carriage of oversized project cargo is primarily based on the assessment of the ship's performance in a situation where the ship is being loaded in bulk by cargo (from Europe) and in the opposite direction (from Southeast Asia) for transportation of oversized project cargo. Considering that the design of dry cargo and container vessels is not optimal for such kind transportation, in most cases, some research is needed to adapt such non-specialized vessels for the transportation of heavy and oversized cargo, to optimize the loading, stowage and securing ensuring safety of cargo during sea passage. In some cases in order to assess the suitability of the vessel her cargo compartments, decks and hatches, its strength, security means and entire safety of the ship, it may also be necessary to apply additional measures to rebuild structural components and ship devices. Therefore, the issues related to the development of measures aimed at improving the efficiency of maritime transport, based on the specifics of the structure of cargo flow, are quite essential. The scope of this work is to discuss some perspectives and practical aspects of ships selection, considering possibility to engage them for transportation of project cargoes and work at economical speeds. Shipping companies often report figures in TCE (time charter equivalent) values so that investors can compare performance of ships operating in the spot and time-charter markets.

Key words: oversized project cargo, time charter equivalent, freight rate.

Introduction. The freight market has a tough competitive environment, where the oversized and heavy lift cargo transportation facing the increase of requirements for loading techniques and transportation technologies. Therefore, for each individual project it is necessary to elaborate and develop the process of implementation the transportation technologies that are significantly different from the standard or conventional ones and it remains as a major challenge. Among that, such transportation projects are developing in accordance with respective industry rules where the all requirements and approvals to be granted upon the initial stage of the process by the governing authorities, up to approval of the necessary rigging equipment for moving and transporting cargo. The object of this article is to discuss some perspectives and practical aspects of ships selection, in view of possibility of their operation for transportation of project cargo using time charter equivalent (TCE) calculation.

Literature review. A wide range of issues related to the technological and economic aspects of the transportation of heavy and oversized cargo reviewed in sources [1-3]. In [4] the world market of heavy and oversized cargoes analyzed and the tendencies of its development are studied. Articles [5;6] analyzed the current state of research in the field of organization and improvement of oversized cargo transportation and considered the prospects for further research with the development of modern models of management of oversized cargo transportation to Ukraine using river-sea transport. Article [7] deals with the safety of the process of transportation of oversized cargo by sea and particularly, as a deck cargo on modern ships.

Dependence research of fuel consumption on the speed mode of ships and methods of selection the optimal operating speed carried out in sources [8-11]. Thus, the article [8] analyzes the types of speed of the vessel and substantiates the choice of the speed of the vessel taking into account the interests of the charterers and the ship owners. The issues of selection the optimal operating speed of ships during operational freight activity considered in sources $[9 ; 10]$. 
In source [11] methods of research of technical and economic indicators of work of vessels are stated. The works [12-17] are devoted to determining the optimal operational speed of vessels.

Materials and methods. Nowadays supply chain for a modern infrastructure projects involves numerous manufacturers of many countries, differing contractors and a complicated array of supply routes including any combination of land transport, sea, river, rail, road or air. The water transport and its loading capacities is significantly higher than land vehicles and usually suffices for the largest and heaviest oversized cargo units. Mainly there are three types of cargo, which are commonly in use in shipping industry (see Fig.1):

- Oversized cargo or Out-of-Gauge cargo is the cargo which exceeding standard container dimensions, (also OOG cargo, or abnormal loads).

- Heavy Lift Cargo is installation of indivisible heavy items, which are due to the absence of standardization for water, and land transportation requires special handling as well as special lifting cranes and utilities.

- Project Cargo define a cargo lot considered for transportation as combination of oversized, heavy, high value or a critical pieces of equipment.

The transportation of oversized or heavy cargo units with specific requirements for loading, stowage and securing processes generally carried out on specialized vessels, which have technical characteristics, and technological capabilities that meet the requirements for the carriage of such cargoes. However, the significant portion of the project cargo transported by non-specialized vessels. Practically there are frequent cases when project cargoes transported on bulk carriers or container ships, (see Fig. 2) whilst the construction of bulk and container carriers is not optimal for such transportation. In most cases, in order to adapt non-specialized vessels for the transportation of heavy and oversized cargo, certain researches to optimize the loading and securing of cargo, assessing the seaworthiness, strength, stability and safety of the vessel are required. In some cases, it may be also necessary justify additional measures for strengthening the ship's construction. Nevertheless, in some cases the use of non-specialized vessels is more economically feasible than the use of specialized vessels respectively. This is due to the specifics of the distribution of the world economy and the distribution of cargo flows. Thus, the countries of Southeast Asia are the largest importers of bulk cargo in the world, as well as exporters of large volumes of project cargo. Therefore, it is quite often situation for laden vessels going to China or S. Korea to face the difficulties to find open freight for reverse direction and they forced to return ballasted. Except that there are also a large number of shipyards in the region, which annually deliver a significant number of new building vessels and vessels after dry-dock maintenance and repair. Thus, there is large percentage of open

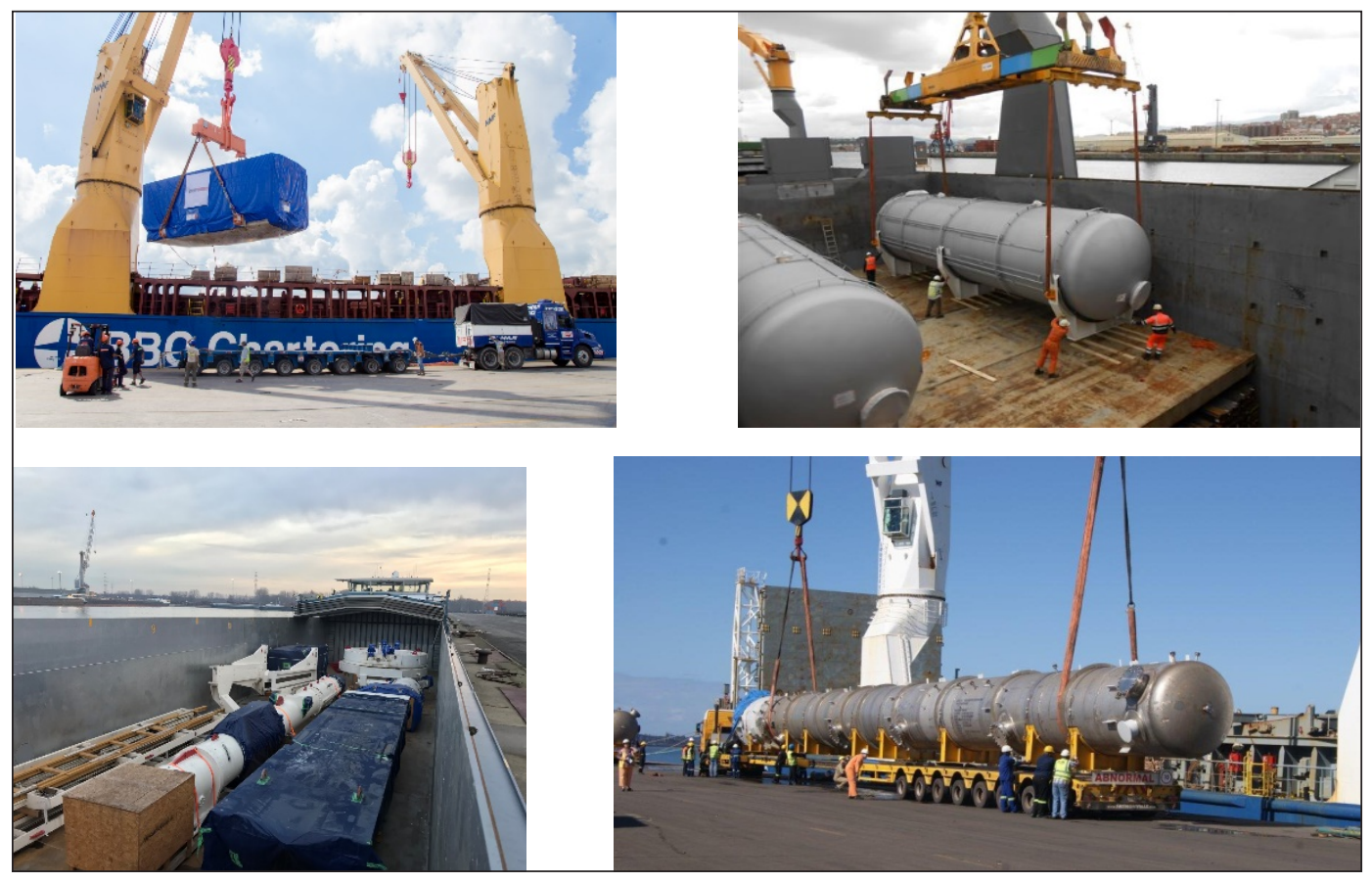

Fig. 1. Loading and stowage of the project cargo. Source Schryver \& GGGate 
tonnage in the region. Although most of these vessels are not designed to carry project cargoes, in some cases it may be more economically effective to use these vessels for project cargo transportation than to carry ballast instead. At one end of the break bulk market are crane-equipped general cargo ships. They tend to run a liner-like service and seek "triangulation" - i.e. to carry cargo on each leg of a long sea-going voyage consisting of several trade lanes. The end goal is to return to the point of origin without ever having suffered an empty ship [19].

Assessment of performance of non-specialized vessels in transportation of project cargo can be started from evaluation of the efficiency of the ship's operation in the situation when in the forward direction the ship has been loaded with bulk cargo (from Europe) and in the opposite direction (from SouthEast Asia) - project cargo.

One of the indicators that is widely used to evaluate a ship's operating efficiency is the time charter equivalent (TCE). The TCE is a standard shipping industry performance measure used to compare period-to-period changes in a company's performance.

$$
T C E=\frac{N R-R_{p}}{t_{p}},
$$

Where: NF - is net freight (freight minus the brokerage commission), USD;

$R_{p}$ - variable expenses of the ship-owner in the voyage (fuel costs, payment of port charges, services of stevedore companies and other operations at the ports of loading / unloading), USD;

$t_{p}$ - voyage duration, days.

Practically as example, the dynamics of changes in the $T C E$ values can be considered for a bulk carrier with a deadweight of $40.000 \mathrm{mts}$. Fig. 3 shows a graph of changes in $F R$ (freight rates) for the transportation of grain in bulk from Ukraine to China for a shipment of 35.000-40.000 mts. Changes of the values of lumpsum rates for the transportation of oversized cargo on board of a bulk carrier with a deadweight of $40.000 \mathrm{mts}$ are shown in Fig. 4.

Fig. 5 shows a graph of the changes of the TCE values, calculated according to formula (1), on condition that $F R$ for the transportation of grain from Ukraine to China changes in accordance with the

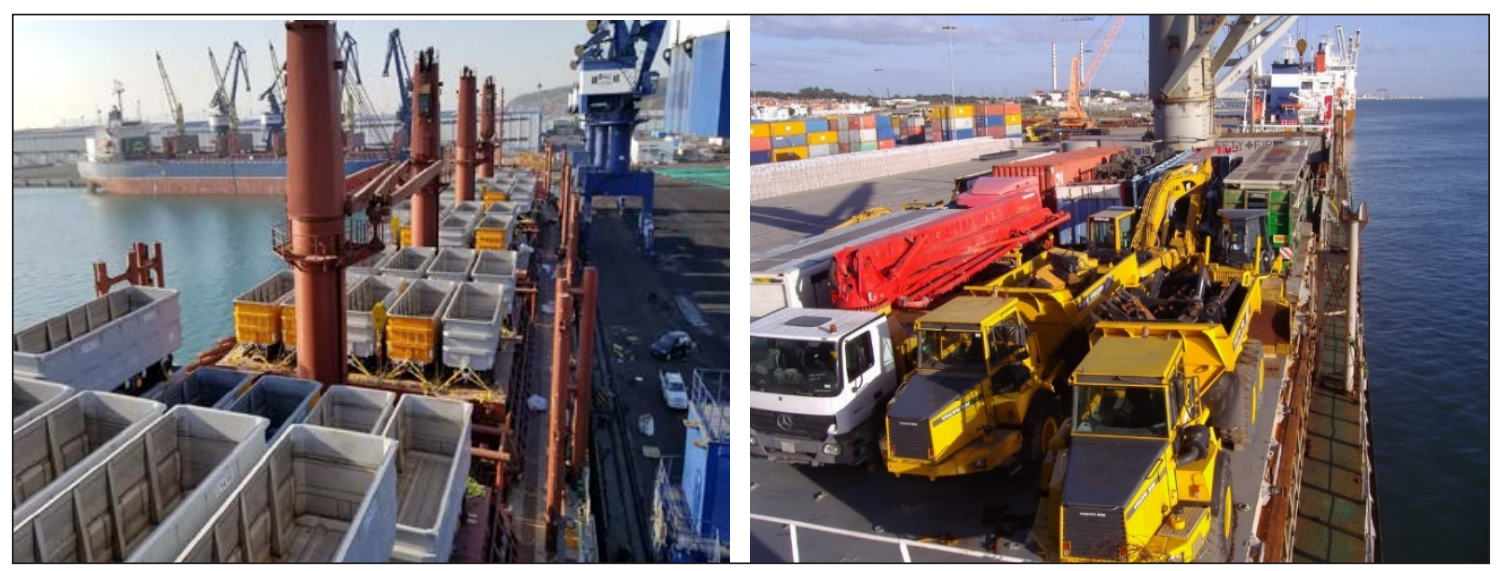

Fig. 2. Bulk carries loaded with deck project cargo. Source Freightwaves

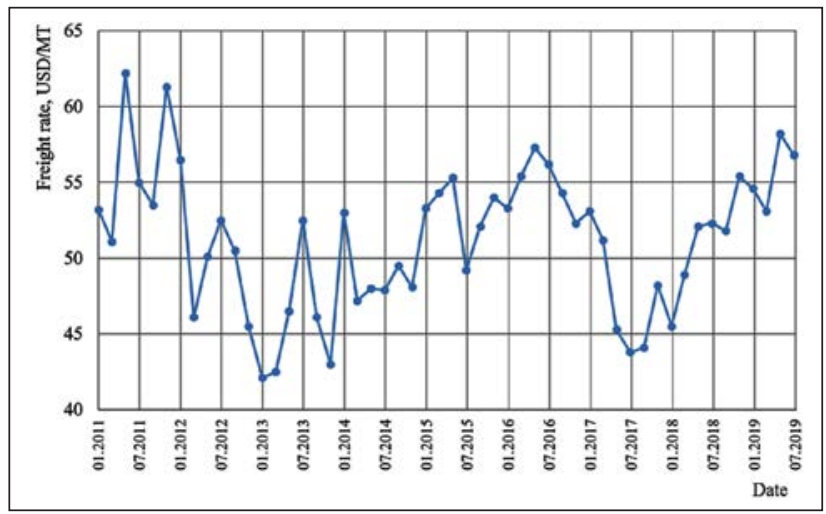

Fig. 3. Freight rate for grain export from Ukraine to China

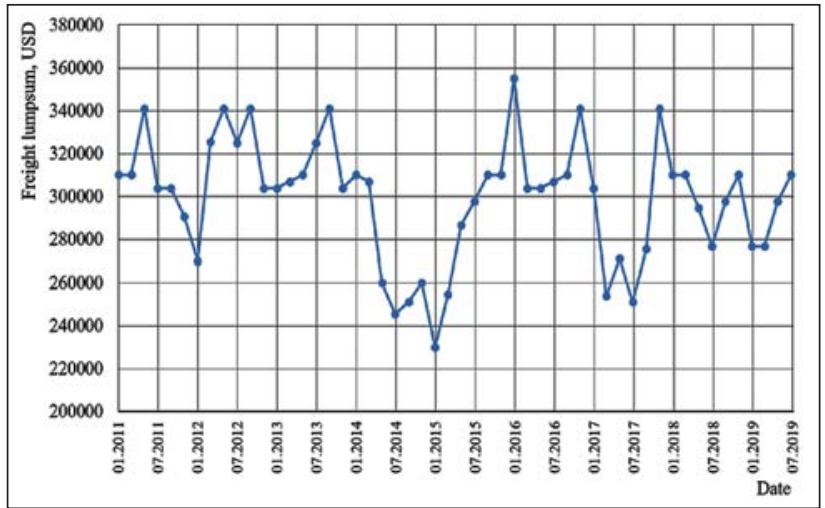

Fig. 4. Lumpsum freight for project cargo export from China to Ukraine (BC dwt $40 \mathrm{~K} \mathrm{mts}$ ) 
graph shown in Fig. 3. and lumpsum rates for project cargoes transported in the reverse direction changed in accordance with the schedule presented in Fig. 4. At the same time, it is assumed that the round trip lasts 67 days, and the variable costs for the round trip to be in amount of 21.000 USD.

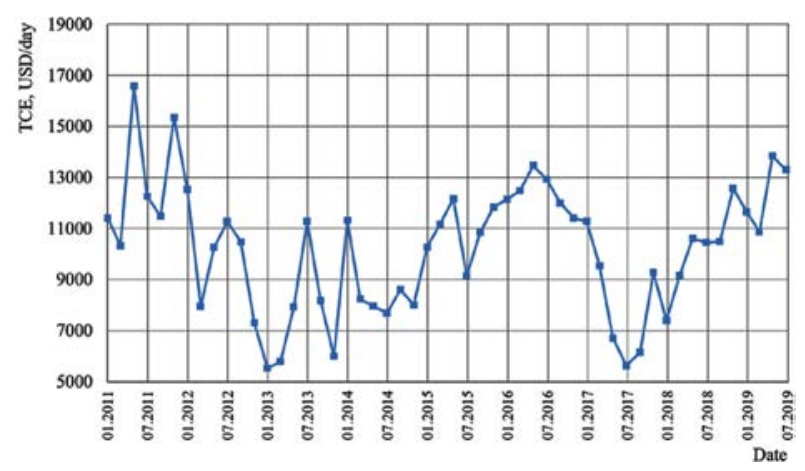

Fig. 5. Time charter equivalent values

A comparison of graphs showing changes in the TCE and the market FRTC (freight rate of the time-charter) for a bulk carrier with a deadweight of 40.000 mts shown on Fig. 6.

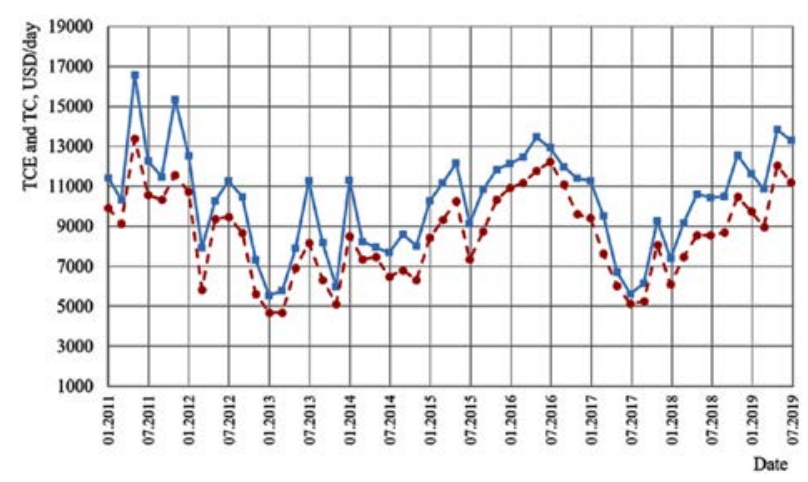

Fig. 6. Comparison of time charter equivalent to time-charter rate

In Fig. 6 described that in case when a bulk carrier is used for project cargo transportation from the Southeast Asia region to the Black Sea region, the average value of the TCE exceeds the market FRTC value by 1600 USD per day. Also in this case, the minimum difference between TCE and FRTC is 500 USD per day, the maximum difference is 3800 USD per day, and the median difference is 1750 USD per day. At the same time, the value of $90 \%$ percentile of the difference between TCE and FRTC is 2100 USD per day, and the value of $10 \%$ percentile is 900 USD per day. Calculations indicate that most of the time ( $80 \%$ of the total observation time) the value of TCE is more than 900 USD per day exceeds market value of FRTC.
In addition, Fig. 6 reveals existence of a relationship between the values of TCE and FRTC, which is also evidenced by the scatter plot shown in Fig. 7 and the fact that the Pearson correlation coefficient between both values TCE and FRTC is 0.97 .

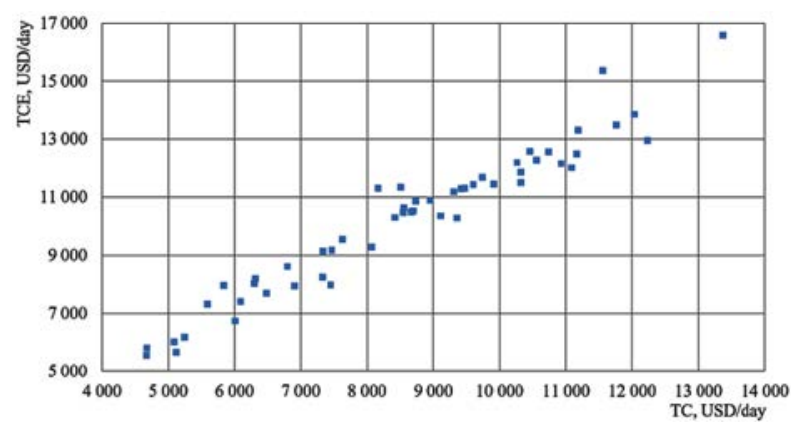

Fig. 7. Scatter plot of time charter equivalent and freight rate values

As it seen on the graphs presented in Fig. 6, it might be supposed that the difference between the TCE and FRTC values increases with the improvement of the freight market tendencies and vice versa becomes smaller when the freight rates decrease. However, this hypothesis does not find confirmation, as evidenced by the scatter plot shown in Fig. 8 and the fact that the Pearson correlation coefficient between FRTC values and deference between TCE and FRTC is only 0.38 .

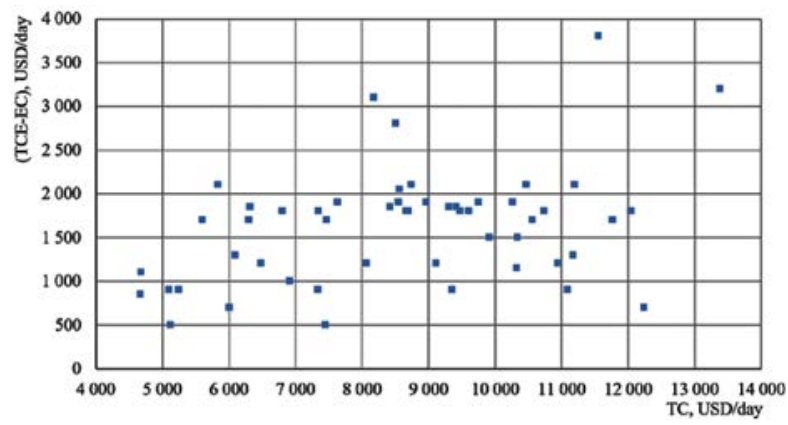

Fig. 8. Scatter plot of freight rate values and deference between time charter equivalent and freight rate

Discussion. When studying the feasibility of taking a dry cargo vessel or bulk carrier in a time charter, ought to consider that in one of directions she might be used for the carriage of project cargo. It is sufficient to calculate the value of the TCE for this vessel in several typical directions where several ships of different types to be considered and evaluated. The efficiency of these vessels, since they will carry bulk cargo in one direction and project cargo in the opposite direction. There are a number of limitations and restrictions, which stipulate the transportation of these types of cargo, technical and operational 
characteristics of the vessels and the parameters of the cargo. The opportunity of efficient use of non-specialized vessels for the carriage of project cargo can be determined by the factors such as the dimensions and design of hatches, the size and shape of holds, deck dimensions, deck equipment and ship's cargo gears. Apart of that, availability of deck standers and structures may interfere with the stowage and disposition of cargo, maximum permissible loads and allowable strength limits may have impact on the deck cargo distribution and methods of deck cargo securing, the influence of the deck cargo on the ship's seaworthiness and navigation safety, maneuverability and others.

Conclusions. The value of average TCE evaluated by the formula for all provided applicant vessels under conditions they operated at passport speeds. $T C E$ shows the profit that the ship-owner receives on the daily basis of operation of the vessel, without deducting the costs of maintaining the vessel (operating costs), which are constant. By comparing the $T C E$ obtained from the preliminary calculation of the proposed traffic, the ship-owner can evaluate which proposal is most profitable for him. It can also compare $T C E$ with the proposed time-charter rental rate, which will help to decide whether to fix the vessel on a time-charter or whether it is profitable to do it on a voyage basis. Bulk carriers and dry cargo vessels are less suited for carriage of oversized cargo than specialized vessels. However, dry cargo vessels a subject for hire at much cheaper rates. As a result, when making a reasonable choice of vessel type and $T C E$ comparison, operating revenues of dry cargo vessels may exceed the operating revenues of specialized vessels. Data analysis showed that for some types of non-specialized dry cargo vessels the value of the TCE significantly exceeds the FRTC market values, which opens new opportunities for non-specialized vessels to be effectively used in project cargo transportation. Therefore, further research aimed at developing more advanced methods for assessing the efficiency of operation of ships and substantiating the optimal selection techniques for non-specialized vessels, taking into account the possibility of their use for transportation of project cargoes, is of great practical interest.

\section{References:}

1. V. Pavlov, N. Troitskaya (1995) Transportation of bulky and heavy cargo. Moscow : Transport. S. 7-17, 41-48.

2. T. Amirov (1985) Transportation of bulky heavy cargo. Moscow : Express Information of the Central Scientific and Technical Library of the Ministry of Transport. Issue 7. S. 41-47, 49-52.

3. G. Pisarevsky. The economy of transportation of bulky goods in rail.Moscow: Intext, 1998. 83 p.

4. O. Akimova, O. Melnyk (2018) Organizational aspects of project cargo transporation. Visnik OMNU. No. 3(56).

5. O. Melnyk (2019) Overview of the state of research of transportation of oversized cargoes in Ukraine, "Transport Systems and Technologies" Issue 34.

6. O. Melnyk (2019) Problem statement and prospects for the development of oversized cargo transportation in Ukraine. Shipping and Navigation. Issue 29.

7. O. Melnyk (2019) Safety issues of oversized cargo transportation be sea. Scientific and Technical Collection "Municipal Economy of Cities" Issue 152, vol 6.

8. O. Shibaev, O. Akimova, (2014) Ship's speed (terminology, concept, content). Modern problems and ways of their solution in science, transport, production and education. Sworld.

9. A. Rakhovetsky (1986) Operational freight activity in maritime transport. Moscow : Transport, 160.

10. A. Rakhovetsky. The effectiveness of the voyage of a sea vessel. Moscow : Transport, 1989.

11. I. Kapitonov. Reserves of the efficiency of operation of sea vessels. Moscow : Transport, 1990. $221 \mathrm{~s}$.

12. I. Lapkina, O. Akimova. Determination of the optimum operational speed of container ships with a change in traffic volumes on the line. Method and management of transport systems development. Number 18, Odessa. 2011. P. 165-181.

13. E. Drozd, I. Kapitonov. (1998) Running mode of ships depending on operating conditions and time-charter. Navigation. 1998. No. 6-7. S. 73-74.

14. I. Lapkina, M. Malaksiano, V. Glavatskih. To the issue of the possibility of operating vessels at slow speeds, Vernadsky. Seriya: Technical Sciences. 2019. V. 30 (69), Part 2, No. 4. P. 134-140.

15. Notteboom T. Fuel surcharge practices of container shipping lines. Institute of Transport and Maritime Management Antwerp. 2009. Vol 37.

16. I. Lapkina, M. Malaksiano, V. Glavatskih. A multicriteria approach to substantiating the choice of a project for the acquisition and operation of a bulk carrier vessel. Sciences Works DUIT. Seriya "Transport systems and technologies". 2019. Vip. 33. T. 2. S. 99-110.

17. F. Vaskevich, O. Kalinin, S. Smolnikov. Choice of the optimal mode of operation of the vessel according to the criterion of maximum profit, taking into account the characteristics of the ship's power plant and external conditions. News of universities. North Caucasian region. Technical science. 2012. No 2. P. 124-127.

18. A. Loshkarev, V. Stepkova. Commercial operation of ships. Workshop Kherson. Kherson State Maritime Academy. 2012.

19. Materials and publications. URL : www.freightwaves.com. 


\section{Малаксіано М.О., Мельник О.М. ОБГРУНТУВАННЯ ВИБОРУ СУДЕН 3 ОГЛЯДУ \\ НА МОЖЛИВІСТЬ ЇХ ВИКОРИСТАННЯ ДЛЯ ПЕРЕВЕЗЕННЯ НЕГАБАРИТНИХ ВАНТАЖІВ}

Краӥни південно-східної Азї̈ є одними з найбільших у світі імпортерів навалювальних вантажів, а також експортерами значних обсягів проектного обладнання, щз складають важковагові та негабаритні вантажі, перевезення яких здійснюються на спеиіалізованих суднах, побудованих та розрахованих під такий тип перевезення. Значна кількість суховантажних суден у тому числі суденбалкерівта контейнеровозів, якіскладають вільнийтоннаж, уцьомугеографічномурайонізалитаються здебільшого без завантаження у зворотному напрямку, тому вимушені здійснювати баластний перехід. Оиінка можливості використання таких неспеціалізованих суден для перевезення негабаритних проектних вантажів, перш за все, базується на оцінюванні ефективності роботи судна в ситуаиії, коли у прямому напрямку судно завантажується навалювальним вантажем (із Свропи), і у зворотному напрямку (з Південно-Східної Азії) воно може бути використано для перевезення негабаритного проектного вантажу. Із погляду на те, щзо конструкиія суховантажів та контейнерних суден не $\epsilon$ оптимальною для таких перевезень, у більшості випадків для адаптаиії таких неспеціалізованих суден для перевезення важких і негабаритних вантажів необхідні також певні дослідження для оптимізаиіі завантаження, розміщення та забезпечення безпеки вантажу під час морського перевезення, оцінки придатності вантажних приміщень та палуб, ӥх міџності, стійкості та безпеки судна у иілому. У деяких випадках може знадобитися також обтрунтування додаткових заходів для переоснащення конструктивних елементів та суднових пристроїв. Тому досить актуальними є питання, що пов'язані з розробленням заходів, щз спрямовані на підвищення ефективності морських перевезень, виходячи із зазначеної специфіки та структури вантажопотоку. Метою даної роботи є розроблення методики обтрунтування вибору суден, зважаючи на можливість їх експлуатачії для перевезень негабаритних проектних вантажів, використовуючи порівняльний аналіз показників ефективності роботи судна.

Ключові слова: негабаритні проектні вантажі, неспеціалізовані судна, фрахтова ставка. 